\title{
Symbolism In Shalat (Prayer): A Conceptual Study on Shalat as The Method of Islamic Education
}

\author{
Drs. Muhammad Muhtar Arifin Sholeh, M.Lib. ${ }^{\mathrm{a}, *}$ \\ ${ }^{a}$ Faculty of Islamic Studies, Sultan Agung Islamic University of Semarang, Indonesia.. \\ *Corresponding author: muhtararifin@unissula.ac.id \& m.muhtaras@ymail.com \\ Article history \\ Received:10/10/2016 \\ Received in revised form:14/01/2017 \\ Accepted:04/03/2017

\begin{abstract}
There is no doubt about the importance of shalat (prayer). As mentioned in the verses of al-Quran and some ahaadiits (prophet traditions), there are some importance of prayer, i.e. as the pillar of ad-diinul-Islam, the character of Muttaqiin (pious people), the direct order from Allah, the first-accounted 'amal (action) in the hereafter, the standard of goodness, the guard from badness, the prove of gratitude, the border between believer and unbeliever, etc-etc. In addition, shalat has many important symbolic meanings which should be implemented in the real life in this world. Symbol can be defined as, by Victor Turner, "a thing regarded by general consent as naturally typifying or representing or recalling something by possession of analogous qualities or by association in fact or thought" (Turner, 1967:19). Shalat is the symbol of life; Shalat has many values which could be implemented in the life. Symbols in shalat can be traced in its requirements, its movements, its recitations, and symbol of congregation (jama'ah). Symbol can be functioned by understanding and implementing it. Furthermore, shalat has four functions, i.e. communicative, educative, integrative, and safety function. In educative function, shalat can be used as a method of Islamic education. The function of shalat can be played by understanding shalat and implementing it. The main purpose of the paper is to explore symbolic meanings of shalat, in order that Muslims can understand and implement those meanings in the real life. In other words, Muslims are hopefully able not only "to do shalat (prayer)" but also "to establish it". Both "ritual prayer" and "actual prayer" have to be implemented in the life. Allah Ta'alaa said, in the translation from al-Quran, "And keep up prayer (establish prayer) and pay the poor-rate and bow down with those who bow down (QS al-Baqarah 2:43). In the context of this ayat, "ritual prayer" is to establish prayer, and "actual prayer" is to pay the poor-rate.
\end{abstract}

Keywords: Shalat, prayer, symbol, symbolism, Islamic education. 


\title{
1.0 INTRODUCTION
}

Ideal Indonesian people is the people with the equilibrium between physics and mental, between spiritual and material thing, between vertical and horizontal relation. Nation building for all Indonesian people is to build all regions of Indonesia. All Indonesian people require multidimensional equilibrium in nation building of Indonesia, which includes all aspects of life. The nation building never wants unidimensional Indonesian people. As mentioned in the Preamble to the 1945 Constitution of the Republic of Indonesia, it is said that:

\begin{abstract}
"Subsequent thereto, to form a government of the state of Indonesia which shall protect all the people of Indonesia and all the independence and the land that has been struggled for, and to improve public welfare, to educate the life of the people and to participate toward the establishment of a world order based on freedom, perpetual peace and social justice, therefore the independence of Indonesia shall be formulated into a constitution of the Republic of Indonesia which shall be built into a sovereign state based on a belief in the One and Only God, just and civilised humanity, the unity of Indonesia, and democratic life led by wisdom of thoughts in deliberation amongst representatives of the people, and achieving social justice for all the people of Indonesia."
\end{abstract}

The majority of Indonesian are Muslim who give a great contribution to nation building of Indonesia. Indonesian Muslims understanding and practicing Islamic teaching, like prayer, fasting, zakat, pilgrimage, etc., are able to make Indonesia more successful, more prosperous, and more advanced. Shalat makes Muslim better character and more civilised. Fasting makes Muslim patient, perpetual peace, and social justice. Zakat makes Muslim achieving social justice, better solidarity, and more democratic. Pilgrimage makes Muslim achieving civilised humanity, solidarity, and unity. Islam means peace so that it can make Indonesia peaceful.

\subsection{THE CONCEPT OF SHALAT (PRAYER)}

Shalat is etymologically meant as 'praying' or 'prayer'. However, shalat is terminologically defined as a worship system including some recitations and actions, which is begun by 'takbirotul-ihram' (raised up the hand with saying 'Allaahu-Akbar') and ended by saying 'salam' (assalaamu'alaikum wa rahmatullaahi wa barakaatuh) while turning the face to right and left, based on with certain requirements), as Razak (1981:178) said, "suatu sistem ibadah yang tersusun dari beberapa perkataan (bacaan) dan laku perbuatan, dimulai dengan takbir dan diakhiri dengan salam, berdasar atas syarat-syarat dan rukun-rukun tertentu".

This kind of worship has to be done five times a day. They are:

1. Fajr or Subuh: Dawn to sunrise, should be performed at least 10-15 minutes before sunrise; there are 2 raka'at.

2. Dzuhur: After true noon until 'Asr; there are 4 raka'at.

3. 'Asr: Afteroon till sunset; there are 4 raka'at.

4. Maghrib: Sunset till dusk; there are 3 raka'at.

5. 'Isya: Dusk till dawn; there are 4 raka'at.

Allah Swt ordered human being to establish shalat, as stated in the Quran, "And keep up prayer (establish prayer) and pay the poor-rate and bow down with those who bow down (QS alBaqarah 2:43). Keeping up prayer (establishing prayer) means performing prayer (called as 'ritual prayer') and then continuing to 'actual prayer', i.e. to actualize (practice) the teachings of 'ritual prayer' such as clean, tidy, sincerity, patience, humbleness, and so on. 'Ritual prayer' means five daily prayers which is well perform. The good quality of 'ritual prayer' can be realized by 'shalatul-khusu' (full obedience and humbleness), by congregation (jama'ah), and in the beginning time. 

pp. $88-97$

Shalat has a very high value and role in Islam. There are some importance of prayer, i.e.:

1. the pillar of ad-diinul-Islam

On the authority of Abdullah ibn Umar ibn Al-Khattab (may Allah be pleased with him) who said: I heard the Messenger of Allah (peace be upon him) say: Islam has been built on five [pillars]: testifying that there is no god but Allah and that Muhammad is the Messenger of Allah, performing the prayers, paying the Zakat, making the pilgrimage to the House, and fasting in Ramadan (narrated by Bukhari \& Muslim).

2. the character of Muttaqiin (pious people)

Aliif laam miim, This Book, there is no doubt in it, is a guide to those who guard (against evil). Those who believe in the unseen and keep up prayer (establish prayer) and spend out of what We have given them (QS al-Baqarah 2:1-3).

3. The remembrance of Allah

Indeed, I am Allah. There is no deity except Me, so worship Me and establish prayer for My remembrance (QS Thaa-haa 20:14).

4. the prove of gratitude

Indeed, We have granted you, [O Muhammad], al-Kawthar. So pray to your Lord and sacrifice [to Him alone]. Indeed, your enemy is the one cut off (QS al-Kautsar 108:1-3).

5. the guard from badness

Recite, [O Muhammad], what has been revealed to you of the Book and establish prayer. Indeed, prayer prohibits immorality and wrongdoing, and the remembrance of Allah is greater. And Allah knows that which you do (QS al-'Ankabuut 29:45).

6. the direct order from Allah

Exalted is He who took His Servant by night from al-Masjid al-Haram to al-Masjid al-Aqsa, whose surroundings We have blessed, to show him of Our signs. Indeed, He is the Hearing, the Seeing (QS al-Isra' 17:1). When Allah revealed the duty of shalat, Muhammad was fetched to meet Allah Himself at Sidhratul-Muntaha during a night journey called Isra' Mi'raj. It is here that Muhammad communicated with Allah directly, and the order of shalat was revealed.

7. the first-accounted 'amal (action) in the hereafter

Yahya related to me from Malik that Yahya ibn Said said, "I have heard that the first of the actions of a slave to be considered on the day of rising is the prayer. If it is accepted from him, the rest of his actions will be considered, and if it is not accepted from him, none of his actions will be considered." (hadits narrated by Bukhari Muslim).

8. the standard of goodness

Yahya related to me from Malik that Yahya ibn Said said, "I have heard that the first of the actions of a slave to be considered on the day of rising is the prayer. If it is accepted from him, the rest of his actions will be considered, and if it is not accepted from him, none of his actions will be considered." (hadits narrated by Bukhari Muslim).

9. the most-frequent worship

Shalat is the most-frequent worship. It includes minimally 5 (five) times a day; 17 reka'at (circles) a day; 17 times for reciting suratul-fatihah a day; 17 times for ruku' (bow down); 34 times for sujud (prostration); and 10 times for reciting salam a day.

10. the border between believer and unbeliever. 
The characteristics of believers is to establish prayer. However, if someone does not (never) pray, he is unbeliever.

There are several functions of the prayer, i.e.:

1. Communicative function

Communication function includes vertical and horizontal communication. Vertical communication means ritual prayer, i.e. communication between human creature and its creator (Allah - the One God). Ritual prayer is five daily-prayers. Horizontal communication means actual prayer, i.e. actualization of the teachings in ritual prayer such as clean, tidy, discipline, humble, patient, sincere, honest, social solidarity, etc.

2. Educative function

Educative function means that prayer (shalat) taught all goodness such as clean, tidy, discipline, humble, patient, sincere, honest, social solidarity, etc. The goodness have to be actualized in the daily life, in order to establish prayer.

3. Integrative function

Integrative function means that prayer in congregation taught unity, togetherness, cooperation, which should be implemented in the social life. Togetherness, cooperation, and brotherhood have to be realized in society.

4. Safety function

Safety function means that prayer can make human being saved in this world and hereafter, because prayer prohibits immorality and wrongdoing.

\subsection{THE SYMBOLS IN SHALAT (PRAYER)}

Victor Turner mentioned the definition of symbol, as he quoted the Concise Oxford Dictionary (Turner, 1967:19), "a thing regarded by general consent as naturally typifying or representing or recalling something by possession of analogous qualities or by association in fact or thought" (sesuatu yang dianggap oleh umum memang menggambarkan atau menyatakan sesuatu yang lain karena mempunyai kesamaan-kesamaan (analog) kualitas atau karena asosiasi dalam kenyataan atau pikiran - translation in Bahasa Indonesia). Symbol can be a physical thing that we can see, touch, and listen to, such as picture, photo, colour in traffic light, sound (including speech), body movement, etc. The meaning of symbol do not intrinsically include in its physical thing.

The main function of symbol is to make easy communication needed by people in life. In other word, among people tend to communicate each other by using language and religion. Language is symbol. People express their oral language by using sound as symbol. They express written language by writing word or sentence as symbol. They also can express their language by body language (body moving/action). Religion is also symbol. Van Baal (1971:249) said, "Religion is a system of symbols by which man communicates with his universe" (agama adalah sistem simbol yang dengan simbol itulah manusia berkomunikasi dengan dunianya - translation in Bahasa Indonesia). Religion (as symbol) can be used as a mean of communication between people and God, as well as people and others. Turner said,

Shalat (prayer) is a religious ceremony or a ritual activity in Islam. In "Dictionary of Anthropology" (Winick, 1977:105), Charles Winick explained the definition of ceremony as "a fixed or sanctioned pattern of behavior which surrounds various phases of life, often serving religious aesthetic ends and confirming the group's celebration of a particular situation" (pola perilaku yang ditentukan atau mengandung sanksi, yang melingkupi berbagai tahap kehidupan, sering untuk memenuhi tujuan estetis religius dan memperkuat perayaan suatu kelompok pada situasi tertentu - translation in Bahasa Indonesia). Noah Webster (1953:146) defined ceremony as "behavior regulated by the laws of strict etiquette" (perilaku yang diatur oleh hukum etika yang tegas - translation in Bahasa Indonesia). 
Shalat is a ritual symbol, i.e. the symbol which is expressed in religious activity and its meaning is realised in social life. According to Victor Turner, the ritual symbol becomes a factor in social action, a positive force in an activity field. The symbol becomes associated with human interests, purposes, ends, and means, whether these are explicitly formulated or have to be inferred from the observed behaviour (Turner, V., 1967:20).

Shalat is the symbol of life; Shalat has many values which could be implemented in the life. Symbols in shalat can be traced in its requirements, its movements, its recitations, and symbol of congregation (jama'ah). Symbol can be functioned by understanding and implementing it.

\subsection{Symbols in Requirements of Prayer}

a. Muslim : status symbol

Muslim is a person who submits to Allah and obey (follow) His command (way), in order to be saved in this world and the hereafter. Muslim submits to Allah and obey (follow) His command (way) by establishing prayer (shalat). Therefore, Muslim is a status symbol describing what should do (roles, function, and activity) in certain status. For example, the status of student should express what they have to do, i.e. going to school, reading, writing, doing homework, doing examination, obeying rule of school, and so on.

b. 'Baligh' (maturation) : real life, understanding, responsibility

'Baligh' means maturation. An accepted shalat is done by matured person. A matured person is a person who understands meaning of life, has responsibility, and gets real life.

c. Healthy mind : high awareness

Islam is ad-diinul-'aql (a rational religion), i.e. its teaching (shalat, fasting, zakat, etc.) can be rationally done. Muslim have to understand his religious teaching. Shalat is commanded by Allah Swt. The man establishing it must have healthy mind. It means that he should be aware of shalat. He has to understand the way of shalat, the recitation of shalat, and the requirement of shalat. Shalat is amanah (trusteeship) from Allah Swt. Therefore, people have to carry it out.

\section{d. Precise time : discipline}

Man's life always concerns with time. Past time, now time, and future time always run for historical stage of man's life. Therefore, people have to understand time and use it efficiently and effectively. Ignoring time makes people aligned from his era, and he cannot catch developing science and technology. Shalat should be performed in the specified time. It means that shalat gave the teaching of time discipline. Allah Swt said:

And when you have completed the prayer, remember Allah standing, sitting, or [lying] on your sides. But when you become secure, re-establish [regular] prayer. Indeed, prayer has been decreed upon the believers a decree of specified times. (QS an-Nisaa 4:103)

e. Clean, tidy :

Before performing shalat, someone must make sure that his body, cloth, place, and even soul cleaned. This duty is applied five times a day, then actualized it in real life of society. Therefore, a good Muslim always make sure that his body, cloth, place, and even soul cleaned. Allah Swt said: "O you who have believed, when you rise to [perform] prayer, wash your faces and your forearms to the elbows and wipe over your heads and wash your feet to the ankles. And if you are in a state of janabah, then purify yourselves. But if you are ill or on a journey or one of you comes from the place of relieving himself or you have contacted women and do not find water, then seek clean earth and wipe over your faces and hands with it. Allah does not intend to make difficulty for you, but $\mathrm{He}$ intends to purify you and complete His favor upon you that you may be grateful." (QS al-Maidah 5:6).

f. Covering 'aurat': keeping secret

Allah Swt said: 

pp. $88-97$

$O$ Prophet, tell your wives and your daughters and the women of the believers to bring down over themselves [part] of their outer garments. That is more suitable that they will be known and not be abused. And ever is Allah Forgiving and Merciful. (QS al-Ahzab 33:59)

Covering 'aurat' is to close part of body that may not be seen. This is the etiquette of wearing cloth when worship. Aurat is also meant 'self-esteem' which is always kept. The Javanese aphorism said, ajining sarira gumantung ana ing busana (good personality depends on wearing cloth). Covering 'aurat' also means keeping secret - personal secret or national/state secret. In this case, 'aurat' is considered as secret.

g. Facing 'kiblat' : circular configuration

The Islamic scholars are agree that facing 'kiblat' ( $k a$ 'bah in Makkah) when praying is requirement of prayer. All Muslims in around the world face 'kiblat' when they are praying. Therefore, ka'bah is a central point of circular configuration. Circular configuration has a deep symbolic meaning. All members of solar system, e.g. earth, mars, mercury, Saturn, etc. go around the sun which is in the central point. Therefore, there will be orbital movement and circular configuration.

In addition, facing 'kiblat' when praying show the unity and togetherness of Muslims around the world, as well as unity of mankind. Muslims establishing prayer have same intention, same purpose, and same movement. They worship same God, follow the example of same Prophet - Muhammad Saw., and obey the same guidance - al-Quran.

\subsection{The Symbols in Movements of Prayer}

If it is mathematically counted, all movements of prayer in one reka'at show 360 degree, which is orbital movement and circular configuration. (Zuhri, 1989:6 ; Ghiffarie, 1987:4). This accounting is as a result of accumulation of six steps in one reka'at of prayer (as shown in the figure/picture below); as follows:

1. Step 1; after takbirotul-ikhrom, when standing up, which shows 0 degree.

2. Step 2; the position of ruku', which shows 90 degree.

3. Step 3; the position of $i$ 'tidal, which shows 0 degree.

4. Step 4; the position of sujud, which shows 135 degree.

5. Step 5; the position of sitting between two sujud, which shows 0 degree.

6. Step 6; the position of second sujud, which shows 135 degree.

Circular configuration and continuous orbital movement is global configuration and continuous natural movement, which makes natural life runs harmoniously. Movement in prayer show steps and natural movement of life.

Movements of prayer show ideal symbol of leadership, regarding head as leader of body. In one reka'at there are three positions of head, i.e. in the upper part (when standing and doing i 'tidal), in the middle part (when doing ruku' and sitting between two sujud), and in the below part (when doing two sujud). It means that a leader ('head') have to give a great attention to all parts (levels) of society, i.e. the upper part of society (e.g. elite), the middle part of society (e.g. academic/school/university society), and the below part of society (e.g. poor people). Furthermore, movements of prayer show a good personality, such as sincerity, patience, humbleness, honesty, and other good characters. 
Figure 1: six steps in prayer
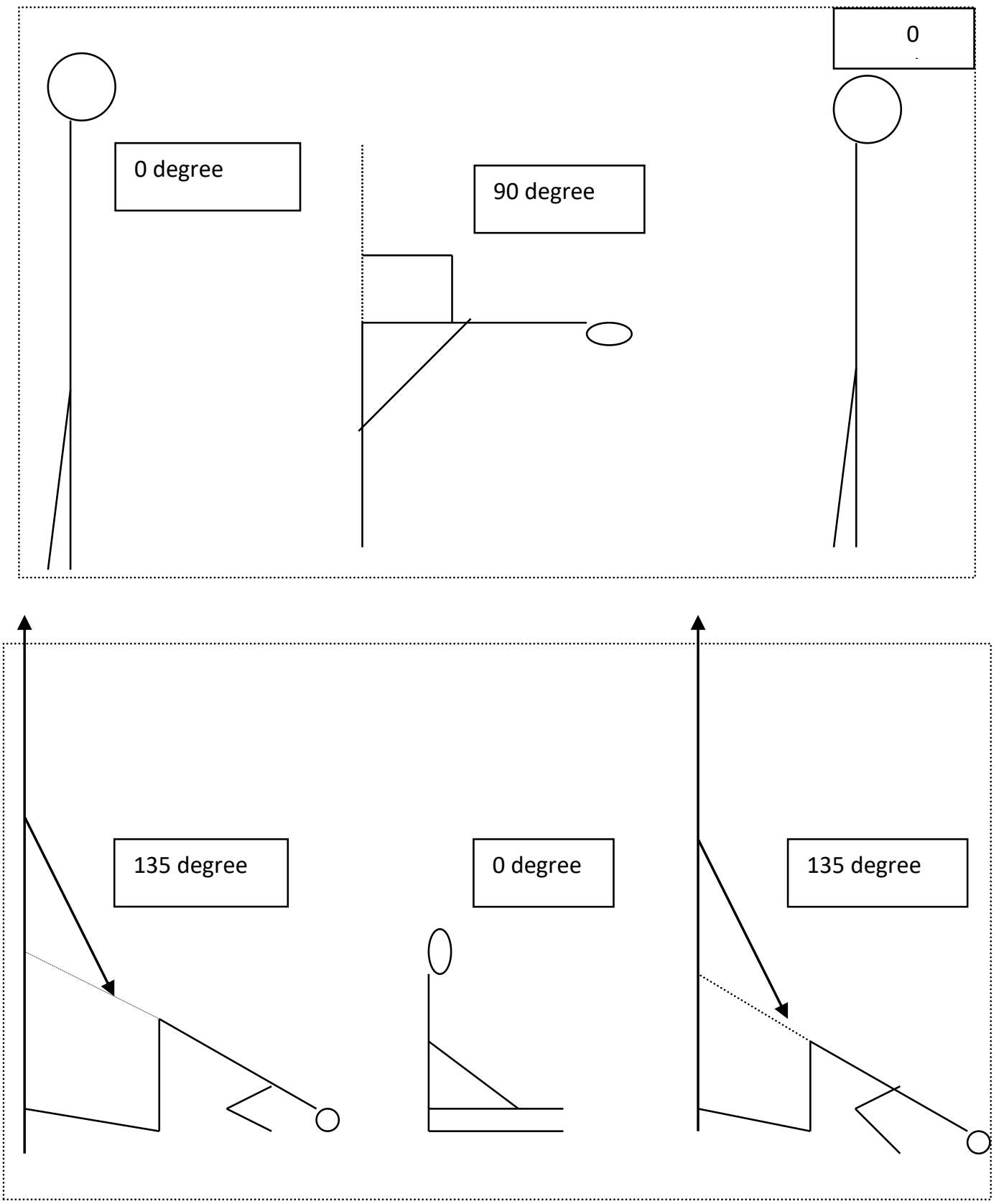

The position of sujud shows symbol of ideal leadership. Sujud gives a good teaching to rich people, in order to give some of their wealth to poor ones. Sujud gives a good teaching to top leader, in order to give a great attention to low level society. Sujud gives a good teaching to diligent (academic) people, in order to share their knowledge. In addition, sujud also gives a good teaching of humbleness and social solidarity. In one day sujud has to be done minimally 34 times, i.e. 17 reka'at multiply two (every reka'at has two sujud).

In short, symbols in movements of prayer can be concluded as follows:

a) The symbols show the life (stage of life) or teaching for life

b) Its movements show circular movement and circular configuration, which is the realization of living nature.

c) The symbols give the teaching of sincerity, honesty, patience, social solidarity, peace, humility, justice, etc. 


\subsubsection{The Symbols in Recitations of Prayer}

a. Shalat is like 'life', its recitation is like dialogue with Allah and talk to other people.

b. All the recitations are good words and goodness which have to be realized in the real life.

\subsubsection{The Symbols of Congregation (jama'ah)}

a. Jama'ah prayer (congregation) gives the teaching of social life and politics.

b. Imam is like 'the leader', ma'mum is like member of society.

c. Imam must be professional, good character, \& good model.

d. Ma'mum have to follow the right imam

\subsection{SHALAT AS METHOD OF ISLAMIC EDUCATION}

In practice a teaching-learning system consists of two systems, i.e. a teaching system and a learning system. A teaching system, which can be also called as an instructional system, refers to a teacher (lecturer), because teaching is the job of a teacher (lecturer), whereas learning system refers to students (learners). However, teaching and learning cannot be separated. A teaching learning system includes inter-related parts (aspects), i.e. human resource, purpose, material, methodology, media, and evaluation. The teacher (lecturer) and student (learner) are considered as a human resource aspect, which can be the most important aspect of teaching learning system because it is living creature, whereas the other factors are non-living creatures.

Methodology is also considered as an important aspect of teaching. It refers to the skill of how teacher well teach. It includes approach, model, strategy, method, and technique of teaching. Teaching approach is the teacher's attitude toward teaching material, i.e. it is rational, emotional, functional, structural, communicative, or ethics approach. Teaching model of is a plan or pattern which we can use to design face-to-face teaching in classrooms or tutorial settings, as well as to shape teaching materials - including books, journals, films, tapes, and computer-mediated programs.

There are many teaching methods, e.g. lecture (speech), dialogue, discussion, practice, exercise (drill), study visit, etc. Therefore, teacher must know how to select the suitable one. Teaching method relates to instructional purpose, material, and media. Each teaching method has advantages and disadvantages. There is no perfect teaching method, so that it is necessary to combine some different methods, e.g. speech and dialogue method. Butcher et.al. (2006:72-73) mentioned some factors which can direct choice of teaching and learning method, as follows:

1. student grouping (large or small group, individual, distance or face to face);

2. role of the tutor (tutor-led or tutor-less; directing, guiding or monitoring);

3. educational technology (supported or mediated by);

4. minds-on (theory based) or hands-on (practically based)

5. stage in the programme (to ensure progression)

In addition, the methods should reflect the needs of the students, the type of material content, and the resources available. To decide an appropriate method, it should be clear the purpose to be reached. In this case, a teacher must know various methods.

Some methods can be used in Islamic education. Shalat having many important symbolic meanings includes some methods of Islamic education, i.e. Al-Bayan (explanation), Al- Amal (practice), Al-Uswah (good model), As-Safar (journey), Al-Qashash (History), dan Adz-Dzikr (Remembrance).

Al-Bayan (explanation), QS an-Nuur 24:58

O you who have believed, let those whom your right hands possess and those who have not [yet] reached puberty among you ask permission of you [before entering] at three times: before the dawn prayer and when you put aside your clothing [for rest] at noon and after the night prayer. [These are] three times of privacy for you. There is no blame upon you nor upon them beyond these [periods], for they continually circulate among you 
- some of you, among others. Thus does Allah make clear to you the verses; and Allah is Knowing and Wise. (QS an-Nuur 24:58)

Al-'Amal (practice), QS al-Israa 17:84 ; Thaa-Haa 20:112

Say, "Each works according to his manner, but your Lord is most knowing of who is best guided in way." (QS al-Israa 17:84)

But he who does of righteous deeds while he is a believer - he will neither fear injustice nor deprivation. (QS Thaa-Haa 20:112)

Al-Uswah (good model), QS al-Ahzaab 33:21

There has certainly been for you in the Messenger of Allah an excellent pattern for anyone whose hope is in Allah and the Last Day and [who] remembers Allah often. (QS al-Ahzaab 33:21)

As-Safar (journey), QS ar-Ruum 30:42

Say, [O Muhammad], "Travel through the land and observe how was the end of those before. Most of them were associators [of others with Allah]. (QS ar-Ruum 30:42)

\section{Al-Qashash (History), QS Yusuf 12:111}

There was certainly in their stories a lesson for those of understanding. Never was the Qur'an a narration invented, but a confirmation of what was before it and a detailed explanation of all things and guidance and mercy for a people who believe. (QS Yusuf 12:111)

\section{Adz-Dzikr (Remembrance), QS al-Hadiid 57:16}

"Has not the time come for the hearts of those who believe (in the Oneness of AllahIslamic Monotheism) to be affected by Allah's Reminder (this Qur'an), and that which has been revealed of the truth, lest they become as those who received the Scripture [the Taurat (Torah) and the Injil (Gospel)] before (i.e. Jews and Christians) and the term was prolonged for them and so their hearts were hardened? And many of them were Fasiqun (the relbellious, the disobedient to Allah". (QS al-Hadiid 57:16).

\subsection{CONCLUSION}

There are some importance of prayer, i.e. as the pillar of ad-diinul-Islam, the character of Muttaqiin (pious people), the direct order from Allah, the first-accounted 'amal (action) in the hereafter, the standard of goodness, the guard from badness, the proof of gratitude, the border between believer and unbeliever, etc-etc. In addition, shalat has many important symbolic meanings which should be implemented in the real life in this world. Shalat is the symbol of life; Shalat has many values which could be implemented in the life. Symbols in shalat can be traced in its requirements, its movements, its recitations, and symbol of congregation (jama'ah). Symbol can be functioned by understanding and implementing it. Furthermore, shalat has four functions, i.e. communicative, educative, integrative, and safety function. In educative function, shalat can be used as a method of Islamic education. The function of shalat can be played by understanding shalat and implementing it.

The main purpose of the paper is to explore symbolic meanings of shalat, in order that Muslims can understand and implement those meanings in the real life. In other words, Muslims are hopefully able not only "to do shalat (prayer)" but also "to establish it". Both "ritual prayer" and "actual prayer" have to be implemented in the life.

Some methods can be used in Islamic education. Shalat having many important symbolic meanings includes some methods of Islamic education, i.e. Al-Bayan (explanation), Al- 'Amal (practice), Al-Uswah (good model), As-Safar (journey), Al-Qashash (History), dan Adz-Dzikr (Remembrance).

\section{References}


Baal, J. Van. (1971). Symbols for Communication. Netherland: Konin-klijke Van Gorcum and Comp. N. V.

Butcher, C., Davies, C., \& Highton, M. (2006). Designing Learning: from Module Outline to Effective Teaching. London: Routledge.

Didik Ahmad Supadi, Sarjuni, dkk. (2015). Pengantar Studi Islam, cetakan ke-3.

Feisal, Jusuf Amir (1995). Reorientasi Pendidikan Islam. Jakarta: Gema Insani Press.

Firth, Raymond. (1973). Symbols: Public and Private. Ithaca: Cornell University Press.

Foss, Martin. (1949). Symbol and Metaphor in Human Experience. New Jersey: Princenton University Press.

Ghazali-al. (1988). Rahasia-rahasia Sholat (diindonesiakan oleh Muh al-Baqir), cetakan ke-3, Bandung: Karisma.

Ghiffarie, Bahar. (1987). "Gerakan Rekaat dalam Shalat Mewujudkan Gerak Orbital?" Kedaulatan Rakyat, halaman IV, Senin 2 Nopember1987.

Jamaal Abdur Rahman. (2005). Tahapan Mendidik Anak: Teladan Rasulullah Saw (diindonesiakan oleh Bahrun Abu Bakar Ihsan Zubaidi). Bandung: Irsyad Baitus-Salam.

Khalid bin Abdurrahman al-'Ik (2012). Kitab Fiqh Mendidik Anak. (diindonesiakan oleh Dwi and Aguk),

Saboe, A. (1986).Hikmah Kesehatan dalam Shalat. Bandung: PT al-Ma'arif.

Turner, Victor W. (1967). The Ritual Process: Structure and Anti-Structure. Ithaca: Cornell University Press.

Press.

(1984). The Forest of Symbols: Aspect of Ndembu Ritual. Ithaca: Cornell University

White, Leslie A. (1955). "The Symbol, the Origin, and the Basic Human Behavior" dalam Hoebels et.al. Readings in Anthropology. London: Taper Publications, Inc., p.303. 